\title{
Synthesis and Magneto-Structural Characterization of $\mathrm{Yb}_{3}(\mathrm{OH})_{7} \mathrm{SO}_{4} \cdot \mathrm{H}_{2} \mathrm{O}$ : a Frustrated Quantum Magnet with tunable stacking disorder
}

Ningxin Jiang, ${ }^{\dagger}$ Xiaojian Bai, ${ }^{\ddagger}$ John Bacsa, ${ }^{\dagger}$ Martin Mourigal,,${ }^{\ddagger}$ and Henry S. La Pierre ${ }^{\star \dagger \phi}$

†School of Chemistry and Biochemistry, ${ }^{\ddagger}$ School of Physics, and $\phi$ Nuclear and Radiological Engineering Program, Georgia Institute of Technology, Atlanta, Georgia 30332-0400, United States

Corresponding Author

*la_pierre@chemistry.gatech.edu

\section{Table of Contents}

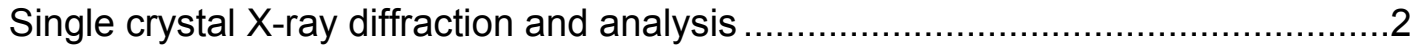

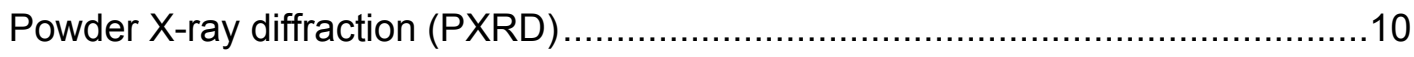

Fourier-transformation infrared spectroscopy (FT-IR) ...................................12

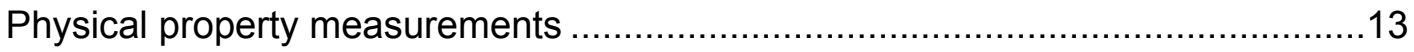

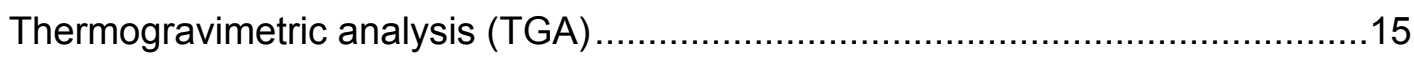

Variable-temperature powder X-ray diffraction ................................................16

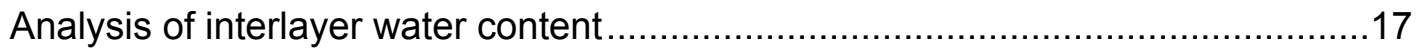

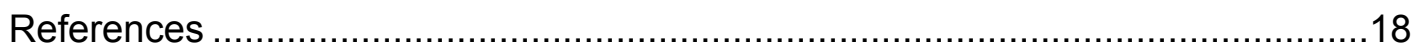


Single crystal $\mathrm{X}$-ray diffraction and analysis

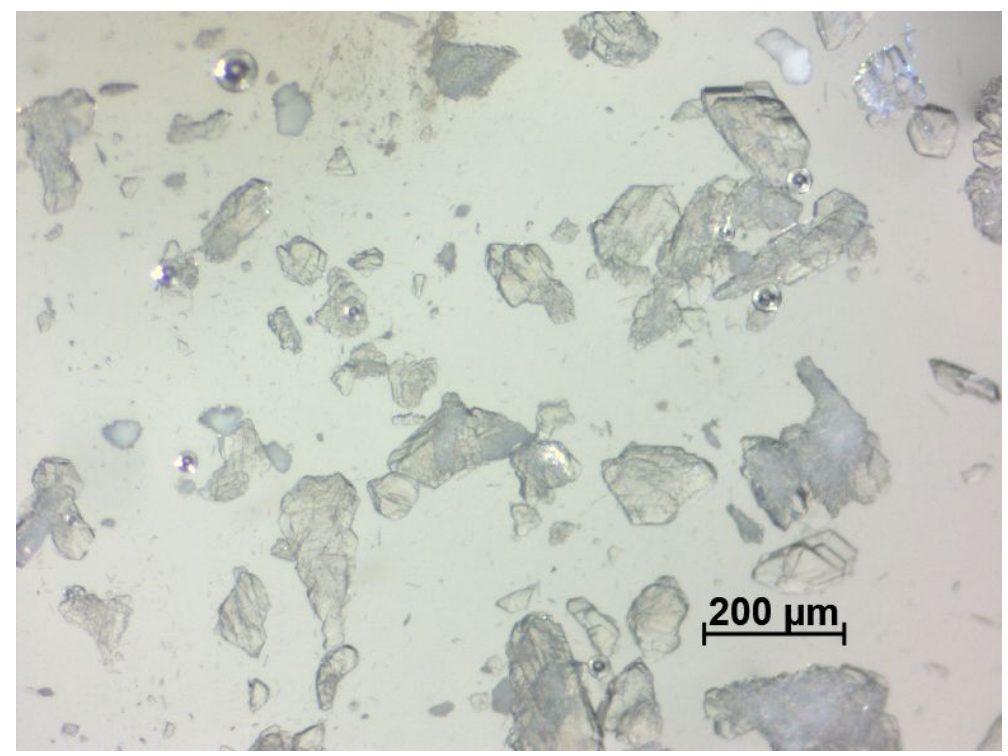

Figure S1. Crystals of 1-Yb 
Table S1. Crystal data and structure refinement for 1-Yb at different temperature

\begin{tabular}{|c|c|c|}
\hline Compound & $\begin{array}{l}\mathrm{Yb}_{3}(\mathrm{OH})_{7} \mathrm{SO}_{4} \cdot \mathrm{H}_{2} \mathrm{O} \\
(1-\mathrm{Yb})\end{array}$ & $\begin{array}{l}\mathrm{Yb}_{3}(\mathrm{OH})_{7} \mathrm{SO}_{4} \cdot \mathrm{H}_{2} \mathrm{O} \\
(1-\mathrm{Yb}-252 \mathrm{~K})\end{array}$ \\
\hline$D_{\text {calc. }} / \mathrm{g} \mathrm{cm}^{-3}$ & 4.917 & 4.892 \\
\hline$m / \mathrm{mm}^{-1}$ & 27.642 & 27.501 \\
\hline $\begin{array}{l}\text { Formula Weight / } \\
\mathrm{g} \cdot \mathrm{mol}^{-1}\end{array}$ & 752.25 & 752.25 \\
\hline Color & colorless & colorless \\
\hline Shape & prism & prism \\
\hline Size $/ \mathrm{mm}^{3}$ & $0.123 \times 0.112 \times 0.051$ & $0.123 \times 0.112 \times 0.051$ \\
\hline$T / \mathrm{K}$ & $100(2)$ & $252(2)$ \\
\hline Crystal System & triclinic & triclinic \\
\hline Space Group & $P_{1}^{-}$ & $P_{1}^{-}$ \\
\hline$a / \AA$ & $7.1021(3)$ & $7.1114(3)$ \\
\hline$b / \AA$ & $8.1824(3)$ & $8.1991(3)$ \\
\hline$c / \AA$ & $9.1785(4)$ & $9.2001(3)$ \\
\hline$\alpha l^{\circ}$ & $103.6915(16)$ & $103.7950(14)$ \\
\hline$\beta /^{\circ}$ & $100.8271(16)$ & $100.9116(14)$ \\
\hline$y I^{\circ}$ & $90.6529(16)$ & $90.4770(13)$ \\
\hline $\mathrm{V} / \AA^{3}$ & $508.13(4)$ & $510.73(3)$ \\
\hline$Z$ & 2 & 2 \\
\hline$Z^{\prime}$ & 1 & 1 \\
\hline Wavelength / A & 0.710730 & 0.710730 \\
\hline Radiation type & $\mathrm{MoK}_{a}$ & $\mathrm{MoK}_{a}$ \\
\hline $\mathrm{Q}_{\min } 1^{\circ}$ & 2.329 & 2.325 \\
\hline$Q_{\max } /^{\circ}$ & 41.175 & 42.092 \\
\hline Measured Refl. & 22638 & 18072 \\
\hline Independent Refl. & 6658 & 6873 \\
\hline $\begin{array}{l}\text { Reflections with I } \\
2 \sigma(I)\end{array}$ & $>5622$ & 5615 \\
\hline $\mathrm{R}_{\text {int }}$ & 0.0547 & 0.0487 \\
\hline Parameters & 165 & 165 \\
\hline Largest Peak & 3.430 & 3.376 \\
\hline Deepest Hole & -2.800 & -2.905 \\
\hline GooF & 1.050 & 1.063 \\
\hline$R_{1}$ (all data) & 0.0485 & 0.0562 \\
\hline$R_{1}$ & 0.0366 & 0.0410 \\
\hline $\begin{array}{l}\text { Occupancy of } \mathrm{Yb}_{\mathrm{b}} \\
\text { site }\end{array}$ & $0.0142(6)$ & $0.0149(7)$ \\
\hline
\end{tabular}


Table S2. Internal angles of triangles in 1-Yb (Using the same labels as Figure S1)

\begin{tabular}{|c|c|c|c|c|c|c|}
\hline $\begin{array}{l}\text { Tria } \\
\text { ngle }\end{array}$ & Angle 1 & Degree $/{ }^{\circ}$ & Angle 2 & Degree $/^{\circ}$ & Angle 3 & $\begin{array}{l}\text { Degree } \\
1^{\circ}\end{array}$ \\
\hline 1 & $\begin{array}{l}\angle \mathrm{Yb} 21- \\
\mathrm{Yb} 11-\mathrm{Yb} 31\end{array}$ & 60.540 & $\begin{array}{l}\angle \mathrm{Yb} 11- \\
\mathrm{Yb} 21-\mathrm{Yb} 31\end{array}$ & 61.843 & $\begin{array}{l}\angle \mathrm{Yb} 11- \\
\mathrm{Yb} 31-\mathrm{Yb} 21\end{array}$ & 57.617 \\
\hline 2 & $\begin{array}{l}\angle \mathrm{Yb} 31- \\
\text { Yb21-Yb32 }\end{array}$ & 63.168 & $\begin{array}{l}\angle \mathrm{Yb} 21- \\
\mathrm{Yb} 31-\mathrm{Yb} 32\end{array}$ & 53.970 & $\begin{array}{l}\angle \mathrm{Yb} 21- \\
\text { Yb32-Yb31 }\end{array}$ & 62.862 \\
\hline 3 & $\begin{array}{l}\angle \mathrm{Yb} 12- \\
\text { Yb11-Yb21 }\end{array}$ & 61.275 & $\begin{array}{l}\angle \mathrm{Yb} 11- \\
\mathrm{Yb} 12-\mathrm{Yb} 21\end{array}$ & 57.107 & $\begin{array}{l}\angle \mathrm{Yb} 11- \\
\mathrm{Yb} 21-\mathrm{Yb} 12\end{array}$ & 61.618 \\
\hline 4 & $\begin{array}{l}\angle \mathrm{Yb} 21- \\
\mathrm{Yb} 12-\mathrm{Yb} 22\end{array}$ & 62.408 & $\begin{array}{l}\angle \mathrm{Yb} 12- \\
\mathrm{Yb} 21-\mathrm{Yb} 22\end{array}$ & 53.933 & $\begin{array}{l}\angle \mathrm{Yb} 12- \\
\text { Yb22-Yb21 }\end{array}$ & 63.659 \\
\hline 5 & $\begin{array}{l}\angle \mathrm{Yb} 22- \\
\text { Yb12-Yb34 }\end{array}$ & 59.728 & $\begin{array}{l}\angle \mathrm{Yb} 12- \\
\text { Yb22-Yb34 }\end{array}$ & 60.009 & $\begin{array}{l}\angle \mathrm{Yb} 12- \\
\text { Yb34-Yb22 }\end{array}$ & 60.263 \\
\hline 6 & $\begin{array}{l}\angle \mathrm{Yb} 33- \\
\text { Yb12-Yb34 }\end{array}$ & 62.107 & $\begin{array}{l}\angle \mathrm{Yb} 12- \\
\text { Yb33-Yb34 }\end{array}$ & 53.951 & $\begin{array}{l}\angle \mathrm{Yb} 12- \\
\text { Yb34-Yb33 }\end{array}$ & 63.942 \\
\hline
\end{tabular}

Table S3. $\angle \mathrm{Yb}-\mathrm{Yb}-\mathrm{Yb}$ angles inside Chain $\mathrm{A}$ and Chain $\mathrm{B}$ in 1-Yb

\begin{tabular}{|c|c|c|}
\hline Angles & Chain & Degree $/^{\circ}$ \\
\hline$\angle \mathrm{Yb} 1-\mathrm{Yb} 2-\mathrm{Yb} 1$ & $A$ & 178.613(9) \\
\hline$\angle \mathrm{Yb} 2-\mathrm{Yb} 1-\mathrm{Yb} 2$ & A & $178.706(8)$ \\
\hline$\angle Y b 3_{a}-Y b 3_{a}-Y b 3_{a}$ & B & $140.851(9)$ \\
\hline
\end{tabular}

Table S4. The distance between the ytterbium and nearest neighbor ytterbium atoms (excluding $\mathrm{Yb3}_{\mathrm{b}}$ ) in 1-Yb

\begin{tabular}{|c|c|c|}
\hline $\mathrm{Yb}-\mathrm{Yb}$ & Distance $(\AA)$ & Percentage \% \\
\hline Yb2-Yb3a & $3.4268(3)$ & 11.11 \\
\hline Yb1-Yb3a & $3.4365(3)$ & 11.11 \\
\hline Yb1-Yb2 & $3.4453(3)$ & 11.11 \\
\hline Yb2-Yb1 & $3.6574(3)$ & 11.11 \\
\hline $\mathrm{Yb3}_{\mathrm{a}}-\mathrm{Yb} 3_{\mathrm{a}}$ & $3.7566(4)$ & 5.556 \\
\hline Yb2-Yb3a & $3.7709(3)$ & 11.11 \\
\hline Yb2-Yb2 & $3.7775(4)$ & 5.556 \\
\hline $\mathrm{Yb}_{\mathrm{a}}-\mathrm{Yb} 3_{\mathrm{a}}$ & $3.7811(5)$ & 5.556 \\
\hline Yb1-Yb3a & $3.8183(3)$ & 11.11 \\
\hline Yb2-Yb1 & $3.8196(3)$ & 11.11 \\
\hline Yb1-Yb1 & $3.8321(4)$ & 5.556 \\
\hline
\end{tabular}


Table S5. Crystal data and structure refinement for 1-Lu

\begin{tabular}{|c|c|}
\hline Compound & $\mathrm{Lu}_{3}(\mathrm{OH})_{7} \mathrm{SO}_{4} \cdot \mathrm{H}_{2} \mathrm{O}(1-\mathrm{Lu})$ \\
\hline$D_{\text {calc. }} / \mathrm{g} \mathrm{cm}^{-3}$ & 5.022 \\
\hline$m / \mathrm{mm}^{-1}$ & 29.652 \\
\hline Formula Weight $/ \mathrm{g} \cdot \mathrm{mol}^{-1}$ & 758.03 \\
\hline Color & colorless \\
\hline Shape & prism \\
\hline Size $/ \mathrm{mm}^{3}$ & $0.189 \times 0.044 \times 0.031$ \\
\hline$T / \mathrm{K}$ & $105(8)$ \\
\hline Crystal System & triclinic \\
\hline Space Group & $\mathrm{P}_{1}^{-}$ \\
\hline$a / \AA$ & $7.06645(16)$ \\
\hline$b / \AA$ & $8.13123(17)$ \\
\hline$c / \AA$ & $9.1302(2)$ \\
\hline$\alpha /^{\circ}$ & $103.5124(19)$ \\
\hline$\beta /^{\circ}$ & $101.094(2)$ \\
\hline$y I^{\circ}$ & $90.0460(18)$ \\
\hline$V / \AA^{3}$ & $499.98(2)$ \\
\hline$Z$ & 2 \\
\hline$Z^{\prime}$ & 1 \\
\hline Wavelength / $\AA$ & 0.710730 \\
\hline Radiation type & $\mathrm{MoK}_{a}$ \\
\hline $\mathrm{Q}_{\min } /^{\circ}$ & 2.579 \\
\hline $\mathrm{Q}_{\max } /^{\circ}$ & 37.785 \\
\hline Measured Refl. & 20593 \\
\hline Independent Refl. & 5346 \\
\hline Reflections with $\mathrm{I}>2 \sigma(\mathrm{I})$ & 4963 \\
\hline $\mathrm{R}_{\text {int }}$ & 0.0383 \\
\hline Parameters & 186 \\
\hline Largest Peak & 3.054 \\
\hline Deepest Hole & -3.447 \\
\hline GooF & 1.054 \\
\hline$R_{1}$ (all data) & 0.0276 \\
\hline$R_{1}$ & 0.0256 \\
\hline Occupancy of Lu3 ${ }_{b}$ site & $0.2006(4)$ \\
\hline
\end{tabular}


Table S6. Refined structural parameters for atoms occupy different positions in two parts of 1-Lu showing fractional coordinates $(x, y, z)$, and the difference between fractional coordinates for correlated atoms.

\begin{tabular}{lllllll}
\hline & $\mathrm{x}$ & $\mathrm{y}$ & $\mathrm{z}$ & $\left|\mathrm{x}_{\mathrm{a}}-\mathrm{x}_{\mathrm{b}}\right|$ & $\left|\mathrm{y}_{\mathrm{a}}-\mathrm{y}_{\mathrm{b}}\right|$ & $\left|\mathrm{z}_{\mathrm{a}}-\mathrm{z}_{\mathrm{b}}\right|$ \\
\hline Lu3 & $0.25428(2)$ & $1.07963(2)$ & $0.51463(2)$ & $0.00635(8)$ & $0.15929(7)$ & $0.02924(6)$ \\
Lu3B & $0.24793(8)$ & $0.92034(7)$ & $0.48539(6)$ & & & \\
S1_1 & $0.29220(13)$ & $0.53571(11)$ & $0.67266(11)$ & $0.5006(4)$ & $0.0025(3)$ & $0.0013(4)$ \\
S1_2 & $0.7928(4)$ & $0.5332(3)$ & $0.6714(4)$ & & & \\
O2 & $0.4604(4)$ & $0.8672(3)$ & $0.5468(3)$ & $0.4994(14)$ & $0.0011(13)$ & $0.0015(12)$ \\
O2B & $-0.0390(14)$ & $0.8683(13)$ & $0.5453(12)$ & & & \\
O4 & $0.0626(4)$ & $0.8671(3)$ & $0.5462(3)$ & $0.5027(14)$ & $0.0007(13)$ & $0.0022(11)$ \\
O4B & $0.5653(14)$ & $0.8678(13)$ & $0.5484(11)$ & & & \\
O5 & $-0.2064(4)$ & $0.7621(3)$ & $0.6746(3)$ & $0.5010(14)$ & $0.0042(13)$ & $0.0002(13)$ \\
O5B & $0.2946(14)$ & $0.7663(13)$ & $0.6748(13)$ & & & \\
O8 & $0.4842(4)$ & $0.6165(4)$ & $0.7574(4)$ & $0.5010(9)$ & $0.0019(10)$ & $0.0020(10)$ \\
O8B & $0.9852(8)$ & $0.6146(9)$ & $0.7554(9)$ & & & \\
O9 & $0.2544(5)$ & $0.5598(4)$ & $0.5154(4)$ & $0.4983(14)$ & $0.0007(11)$ & $0.0006(7)$ \\
O9B & $0.7527(13)$ & $0.5591(10)$ & $0.5148(6)$ & & & \\
O10 & $0.1422(4)$ & $0.6166(4)$ & $0.7555(4)$ & $0.5018(11)$ & $0.0038(11)$ & $0.0008(10)$ \\
O10B & $0.6440(10)$ & $0.6128(10)$ & $0.7563(9)$ & & & \\
O11 & $0.2913(5)$ & $0.3545(4)$ & $0.6719(4)$ & $0.5025(13)$ & $0.0027(6)$ & $0.0025(11)$ \\
O11B & $0.7938(12)$ & $0.3518(5)$ & $0.6694(10)$ & & & \\
\hline
\end{tabular}

For all these correlated atoms except for Lu3 and Lu3B, the differences between fractional coordinates $x$ are close to 0.5 , the difference between fraction coordinates $y$ and $z$ are close to 0 which indicate that part $B$ could overlap with the part $A$ if part $B$ was translated $3.53 \AA$ (half of the lattice constant a) along a-axis. 
Table S7. Crystal data and structure refinement for $\mathrm{Yb}_{3}(\mathrm{OH})_{7} \mathrm{SO}_{4} \cdot \mathrm{H}_{2} \mathrm{O}$ with disorder degree of $23 \%(1-Y b-23 \%)$

\begin{tabular}{|c|c|}
\hline Compound & $\mathrm{Yb}_{3}(\mathrm{OH})_{7} \mathrm{SO}_{4} \cdot \mathrm{H}_{2} \mathrm{O}(1-\mathrm{Yb}-23 \%)$ \\
\hline$D_{\text {calc. }} / \mathrm{g} \mathrm{cm}^{-3}$ & 4.901 \\
\hline$m / \mathrm{mm}^{-1}$ & 27.626 \\
\hline Formula Weight $/ \mathrm{g} \cdot \mathrm{mol}^{-1}$ & 752.25 \\
\hline Color & colorless \\
\hline Shape & prism \\
\hline Size $/ \mathrm{mm}^{3}$ & $0.143 \times 0.073 \times 0.029$ \\
\hline$T / \mathrm{K}$ & $100(2)$ \\
\hline Crystal System & triclinic \\
\hline Space Group & $P_{1}^{-}$ \\
\hline a / $\AA$ & $7.10228(12)$ \\
\hline$b / \AA$ & $8.18109(14)$ \\
\hline$c / \AA$ & $9.18458(14)$ \\
\hline$\alpha /^{\circ}$ & $103.6866(14)$ \\
\hline$\beta /^{\circ}$ & $100.8596(14)$ \\
\hline$y /^{\circ}$ & $90.5518(14)$ \\
\hline $\mathrm{V} / \AA^{3}$ & $508.403(15)$ \\
\hline Z & 2 \\
\hline$Z^{\prime}$ & 1 \\
\hline Wavelength / $\AA$ & 0.710730 \\
\hline Radiation type & $\mathrm{MoK}_{a}$ \\
\hline $\mathrm{Q}_{\min } /^{\circ}$ & 2.328 \\
\hline $\mathrm{Q}_{\max } /^{\circ}$ & 45.294 \\
\hline Measured Refl. & 22851 \\
\hline Independent Refl. & 8436 \\
\hline Reflections with $\mathrm{I}>2 \sigma(\mathrm{I})$ & 6539 \\
\hline $\mathrm{R}_{\text {int }}$ & 0.0425 \\
\hline Parameters & 187 \\
\hline Largest Peak & 3.897 \\
\hline Deepest Hole & -3.608 \\
\hline GooF & 1.031 \\
\hline$R_{1}$ (all data) & 0.0604 \\
\hline$R_{1}$ & 0.0412 \\
\hline Occupancy of $Y b 3_{b}$ site & $0.2283(5)$ \\
\hline
\end{tabular}




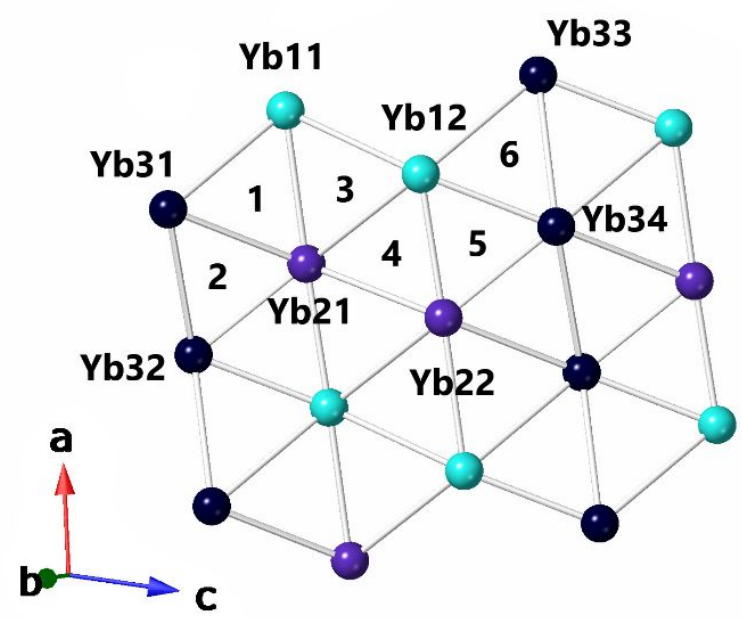

Figure S2. Demonstration of the six triangles in 1-Yb

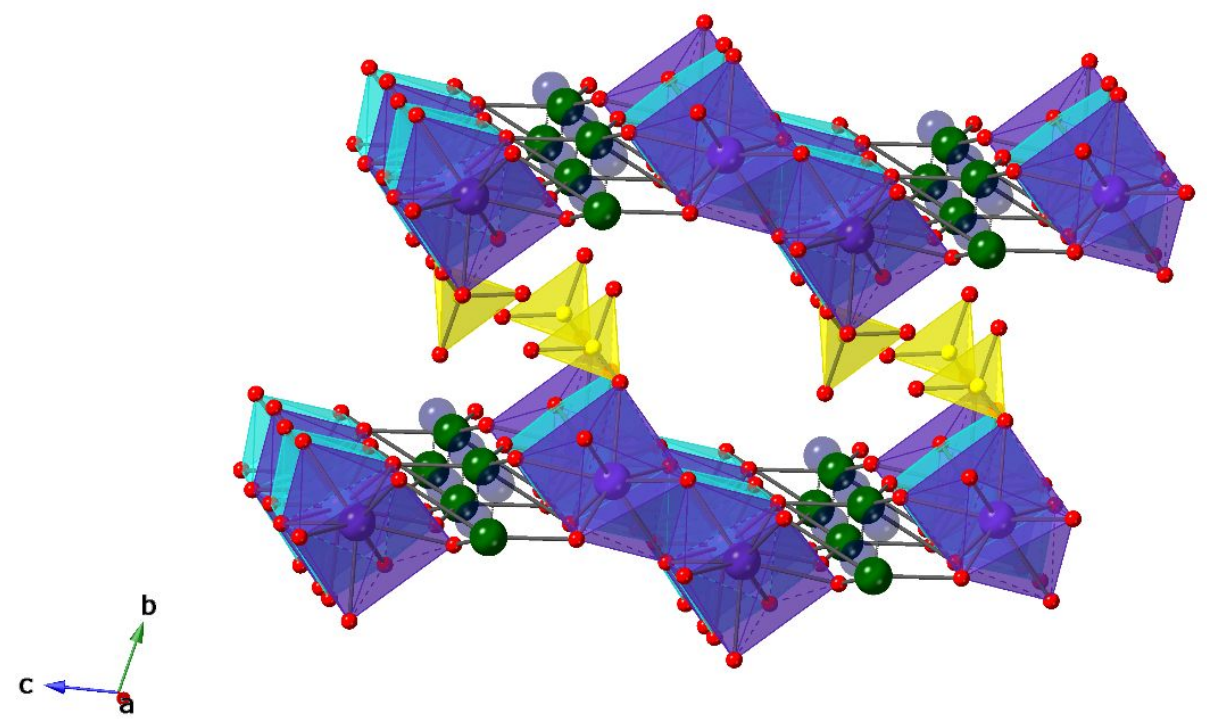

Figure S3. Side view of 1-Yb. Yb1 atoms are cyan, $\mathrm{Yb} 2$ atoms are purple, $\mathrm{Yb3}_{\mathrm{a}}$ atoms are dark blue and translucent $\mathrm{Yb}_{\mathrm{b}}$ atoms are dark green, oxygen atoms are red, sulfur atoms are yellow. The water molecules and hydrogen atoms are omitted. 


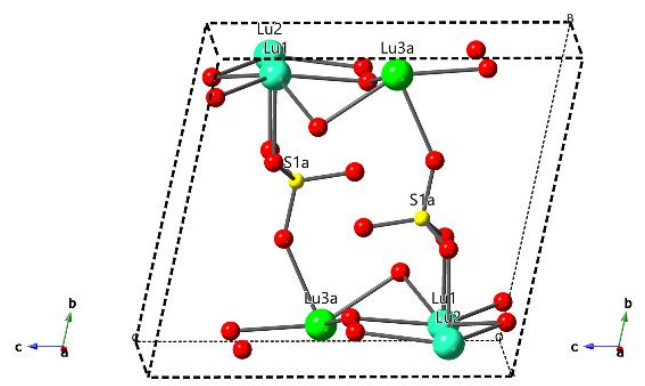

Part A

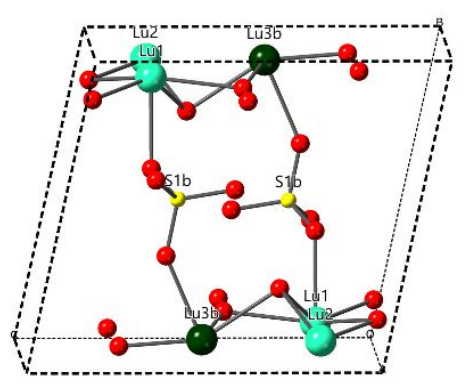

Part B

Figure S4. The unit cell of part A and part B for 1-Lu. Lu1 and Lu2 atoms are cyan, $\mathrm{Lu}_{\mathrm{a}}$ are light green, and $\mathrm{Lu}_{\mathrm{b}}$ atoms are dark green. Four oxygen atoms and two lutetium atoms (Lu1 and Lu2) share the same position in these two parts while the position of seven oxygen atoms, one lutetium atom, and one sulfur atom own different positions in these two parts. The water molecules and hydrogen atoms are omitted.

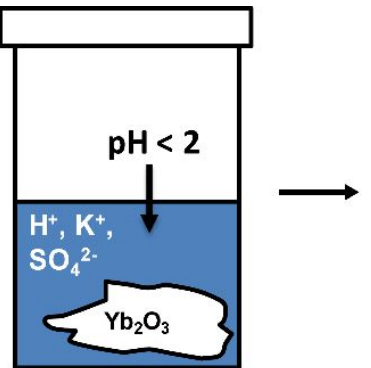

Step 1

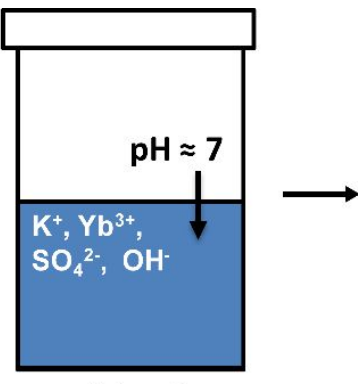

Step 2

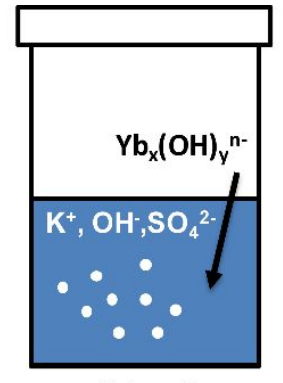

Step 3

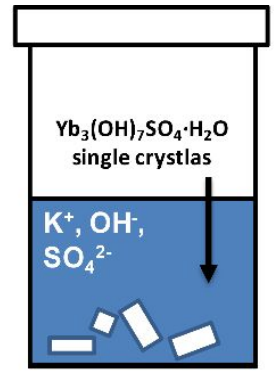

Step 4

Scheme S1. Hypothesized reaction mechanism for the synthesis of $1-\mathbf{Y b}$. At the beginning of the reaction, the $\mathrm{Yb}_{2} \mathrm{O}_{3}$ powder is digested in the acidic condition which leads to the formation of $\mathrm{Yb}^{3+}$ and increases the $\mathrm{pH}$ of the solution. With gradually increasing $\mathrm{pH}$, the $\mathrm{Yb}^{3+}$ ions combine with the hydroxy group and induce the formation of small $\mathrm{Yb}_{\mathrm{x}}(\mathrm{OH})_{\mathrm{y}}{ }^{\mathrm{n}-}$ nucleus in a slow rate. Afterwards, the 1-Yb single crystals are formed under high temperature and high-pressure condition due to the growth of $\mathrm{Yb}_{\mathrm{x}}(\mathrm{OH})_{\mathrm{y}}{ }^{\mathrm{n}}$ - nucleus with sulfate bridging ligands. Crystal growth is independent of cooling rate. Cooling rate ranging from $5{ }^{\circ} \mathrm{C} / \mathrm{h}$ to $20^{\circ} \mathrm{C} / \mathrm{h}$ was used in hydrothermal synthesis and no obvious change in crystal size or degree of disorder was observed.

In the synthesis of $1-\mathrm{Yb}-23 \%$, the $\mathrm{Yb}_{\mathrm{x}}(\mathrm{OH})_{\mathrm{y}}{ }^{\mathrm{n}-}$ nucleus already exists in room temperature due to the reaction between $\mathrm{Yb}_{2}\left(\mathrm{SO}_{4}\right)_{3} \cdot \mathrm{xH}_{2} \mathrm{O}$ and $\mathrm{KOH}$ in the solution. The nucleation process might be much faster in this synthetic procedure which lead to the formation of stacking disorder. 


\section{Powder X-ray diffraction (PXRD)}

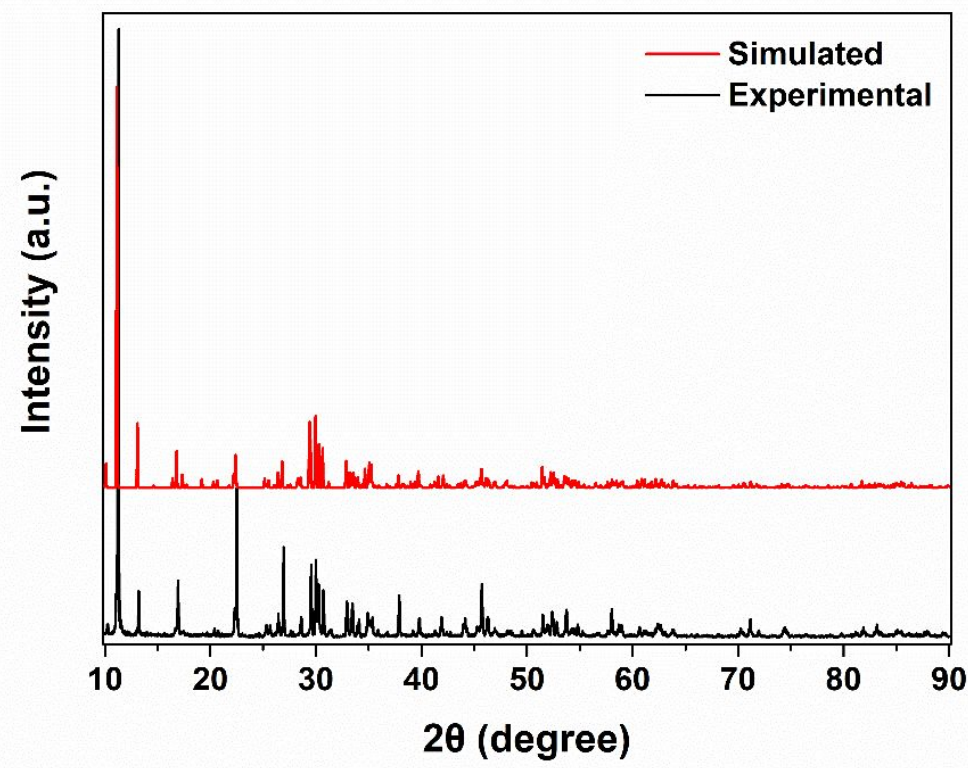

Figure S5. Simulated (red line, simulated from single-crystal $X$-ray structure) and experimental (Black line) powder X-ray diffraction patterns for 1-Yb. There is no obvious difference between the position of peaks in these two patterns which indicate the accuracy of single-crystal X-ray diffraction results and the purity of the assynthesized 1-Yb compound.

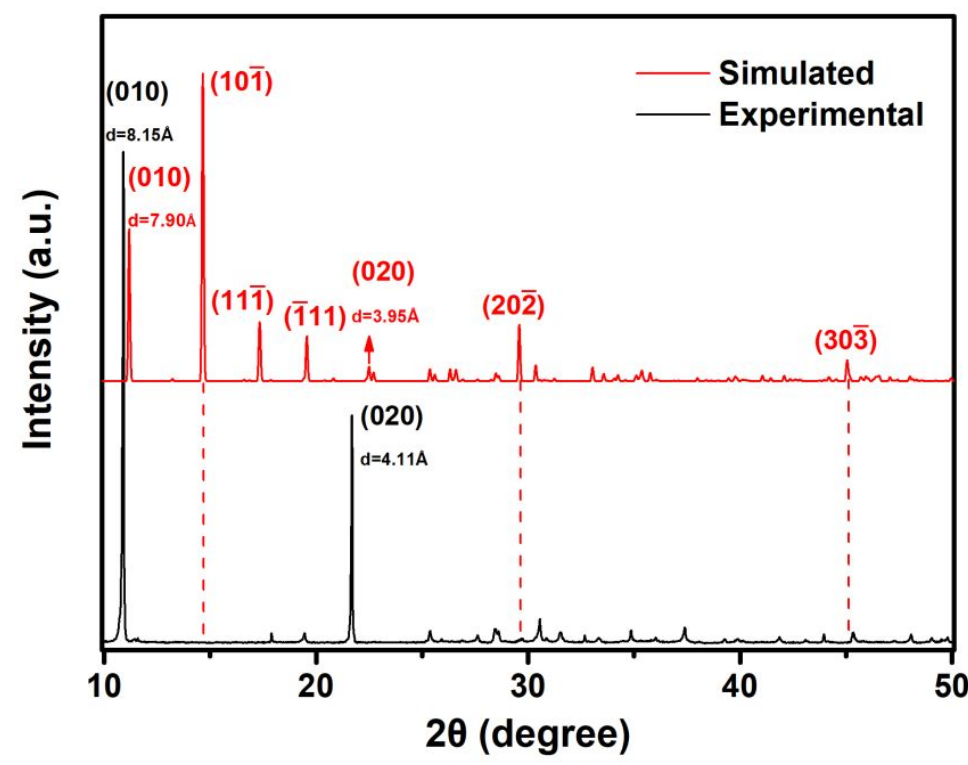

Figure S6. Simulated (red line, simulated from single-crystal $X$-ray structure) and experimental (Black line) powder X-ray diffraction patterns for 1-Lu. The shifts of (010) and (020) reflections might be caused by the difference between the experimental temperature of SCXRD $(100 \mathrm{~K})$ and PXRD (room temperature). At low temperature, 
the crystal shrinks along the direction that perpendicular to the layers and the layer distance decreases which lead to the shift of $(0 \mathrm{k} 0)$ peak to a higher angle. The change of lattice parameter $b$ under different experimental temperatures has also been observed on $\mathbf{1 - Y b}$ as shown in table S1 under $100 \mathrm{~K}$ and $252 \mathrm{~K}$. The vanishing of (10 $\overline{1}),\left(20_{2}\right)$ and $\left(30_{3}\right)$ reflections indicates the damage of long-range periodicity between layers and demonstrates that the disorder in 1-Lu and 1-Yb is stacking disorder. The similar disappearance of reflections is not observed in 1-Yb (Figure S4) which might due to the lower degree of disorder.

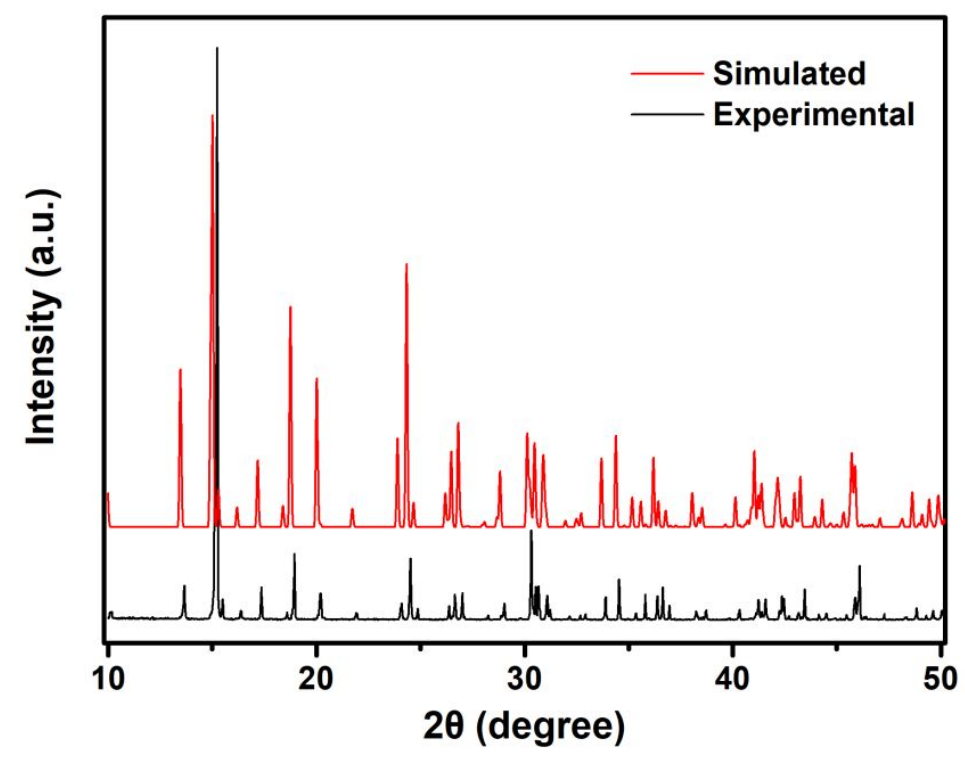

Figure S7. Simulated (red line, simulated from single-crystal $X$-ray structure of $\mathrm{Yb}_{2}\left(\mathrm{SO}_{4}\right) \cdot 8 \mathrm{H}_{2} \mathrm{O}$ from literature ${ }^{1}$ ) and experimental (Black line) powder X-ray diffraction patterns for $\mathrm{Yb}_{2} \mathrm{SO}_{4} \cdot 8 \mathrm{H}_{2} \mathrm{O}$. There is no obvious difference between the position of peaks in these two patterns except a slight shift of all peaks which indicate the purity of the as-synthesized $\mathrm{Yb}_{2} \mathrm{SO}_{4} \cdot 8 \mathrm{H}_{2} \mathrm{O}$. 


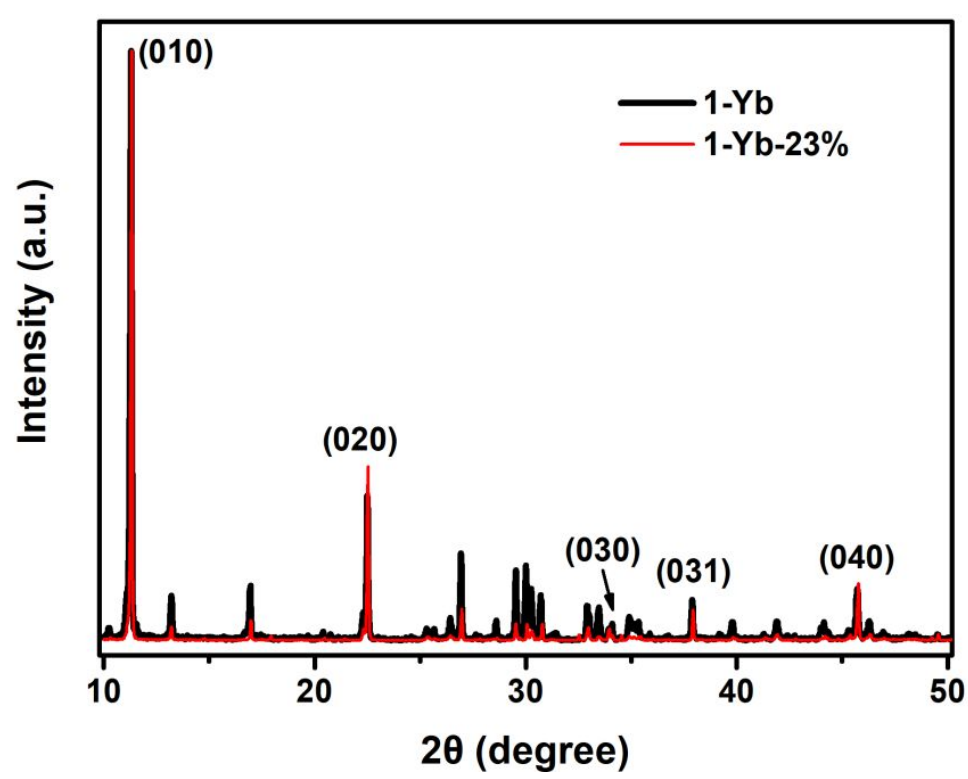

Figure S8. Powder X-ray diffraction patterns for $\mathbf{1 - Y b}$ (black line) and $\mathbf{1 - Y b - 2 3 \%}$ (red line). The data is normalized to the intensity of (010) reflection in the two sample patterns. Only reflections $(0 \mathrm{k} 0)$ are of similar intensity and all the rest reflections are weaker in $1-\mathbf{Y b}-\mathbf{2 3} \%$ in comparison to $1-\mathrm{Yb}$ which can be attributed to the destruction of periodicity between layers.

Fourier-transformation infrared spectroscopy (FT-IR)

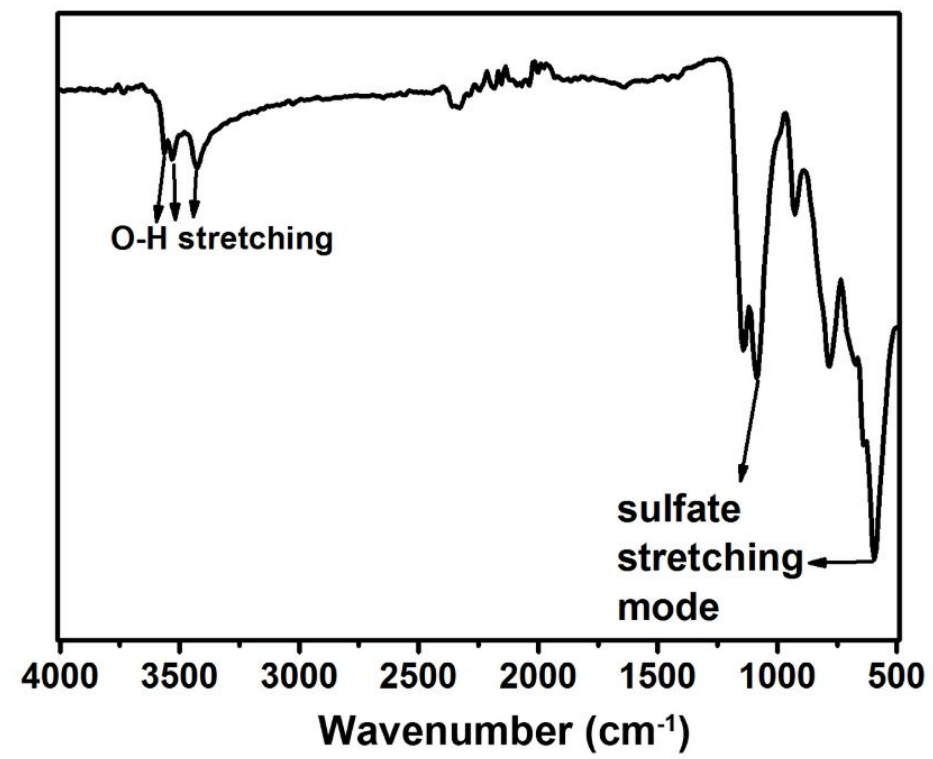

Figure S9. FT-IR results for $1-\mathrm{Yb}$. The $\mathrm{O}-\mathrm{H}$ stretching mode and $\mathrm{SO}_{4}{ }^{2-}$ stretching mode can be observed indicating the presence of these two groups. ${ }^{2}$ 
Physical property measurements

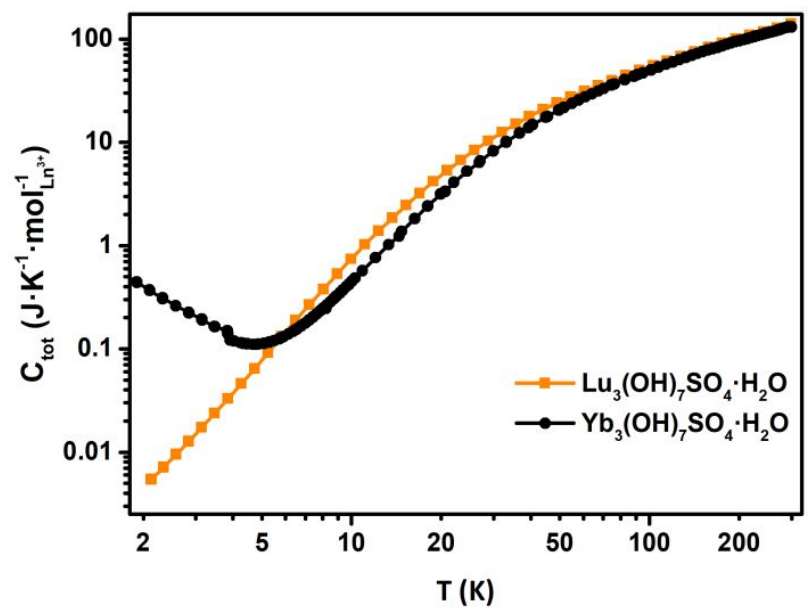

Figure S10. Temperature dependence of total specific heat in 1-Yb and 1-Lu

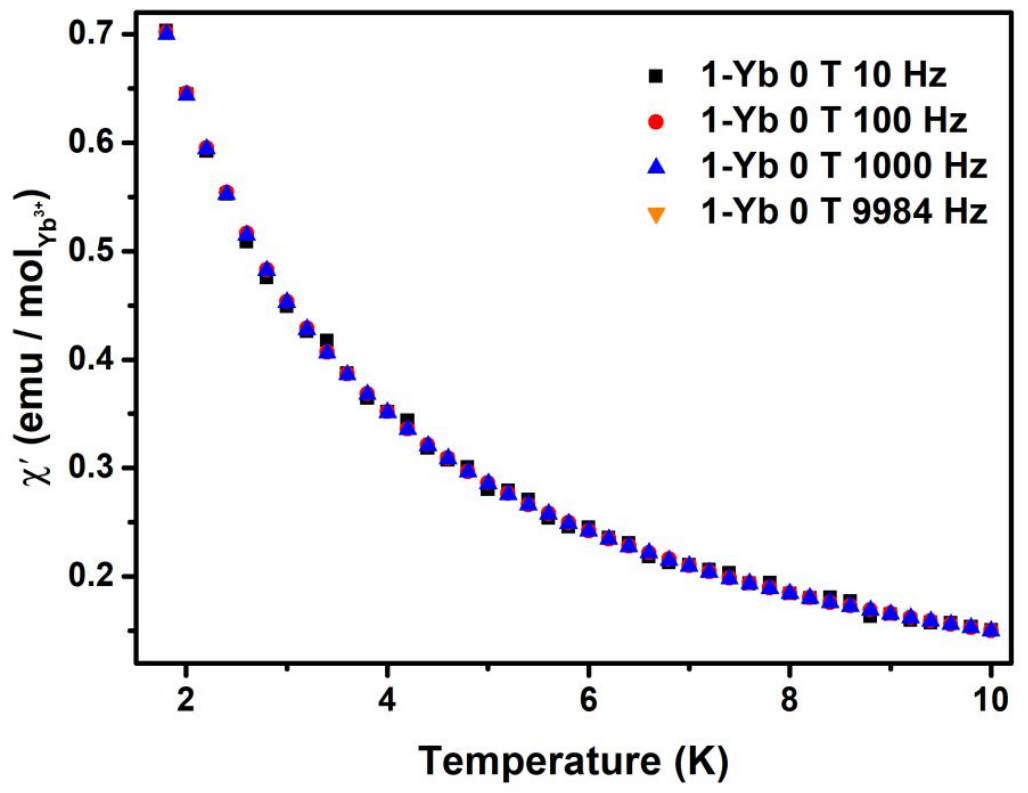

Figure S11. Temperature dependence of the real part of the ac susceptibility $X^{\prime}$ for 1Yb. 


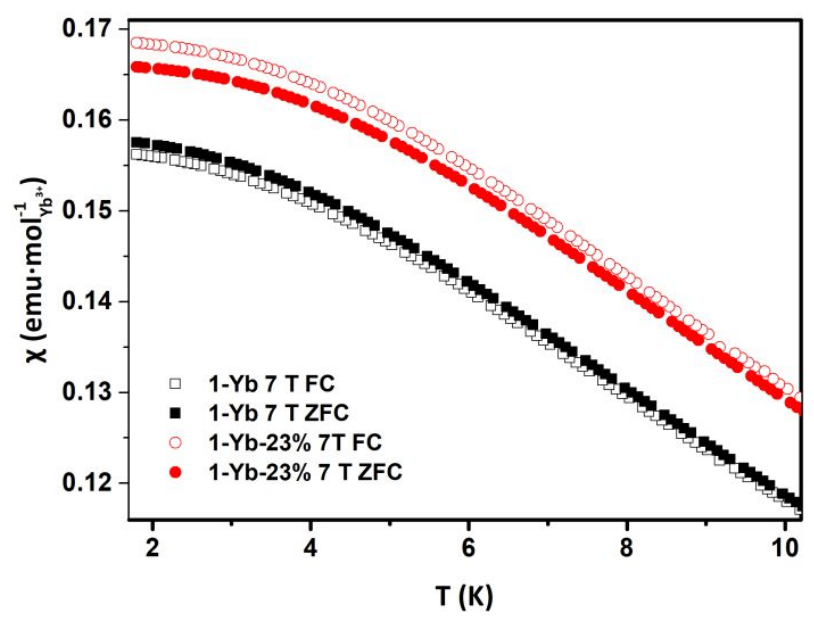

Figure S12. Temperature dependence of magnetic susceptibility measurement for 1Yb and $1-Y b-23 \%$ at $7 \mathrm{~T}$.

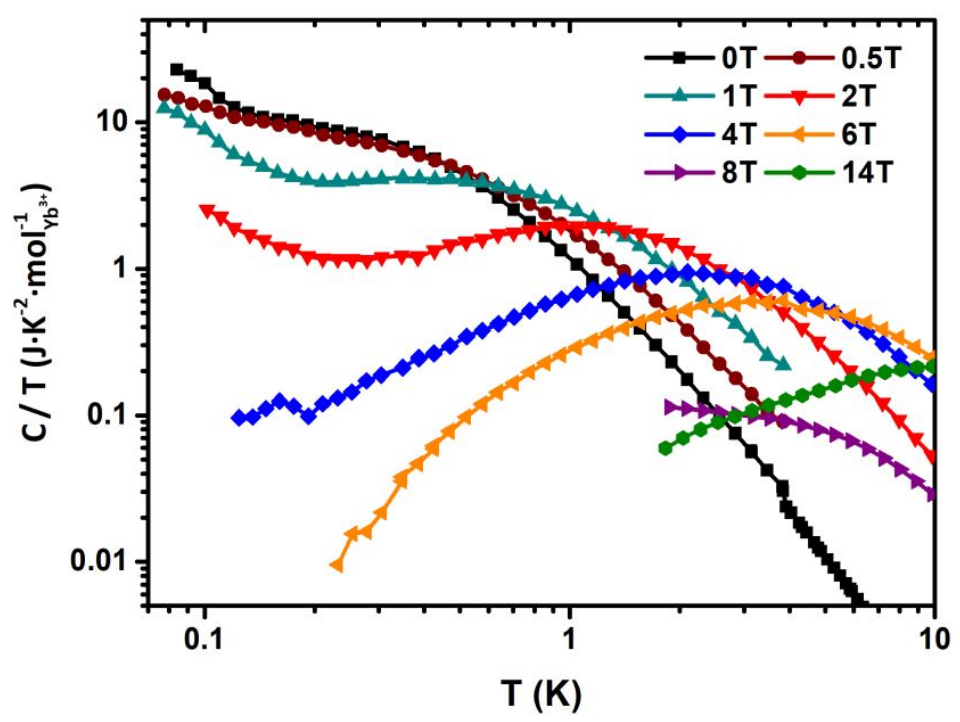

Figure S13. Temperature dependence of $C / T$ under different magnetic fields in 1-Yb. Herein, the lattice contribution has been subtracted and the specific heat consist of nuclear and magnetic specific heat. The upturn of lines at low-temperature indicates the nuclear contribution to the specific heat in the system which is obvious for the $C /$ $\mathrm{T}$ - $\mathrm{T}$ data under $0 \mathrm{~T}, 0.5 \mathrm{~T}, 1 \mathrm{~T}, 2 \mathrm{~T}$, and $4 \mathrm{~T}$ fields. 


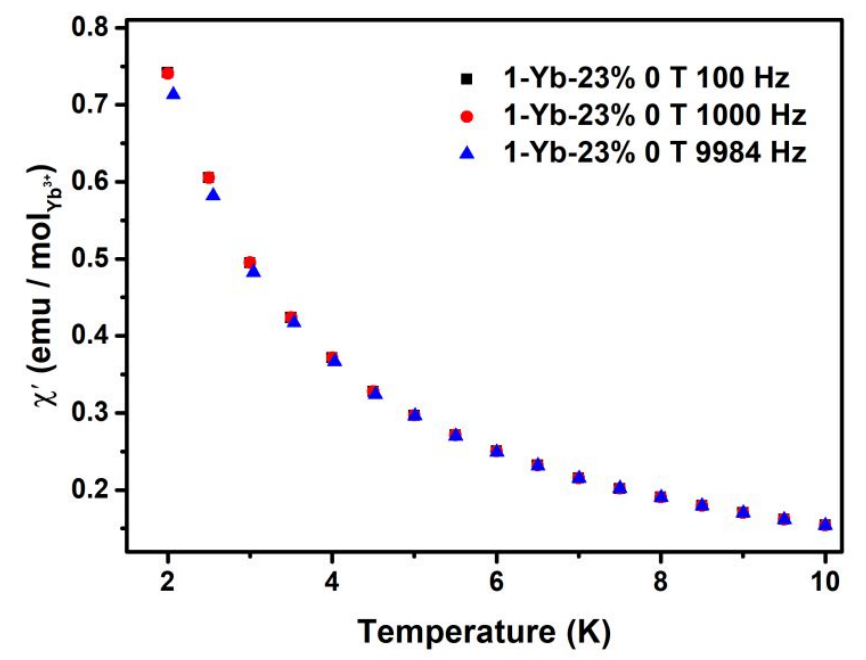

Figure S14. Temperature dependence of the real part of the ac susceptibility $X^{\prime}$ for 1Yb-23\%.

Thermogravimetric analysis (TGA)

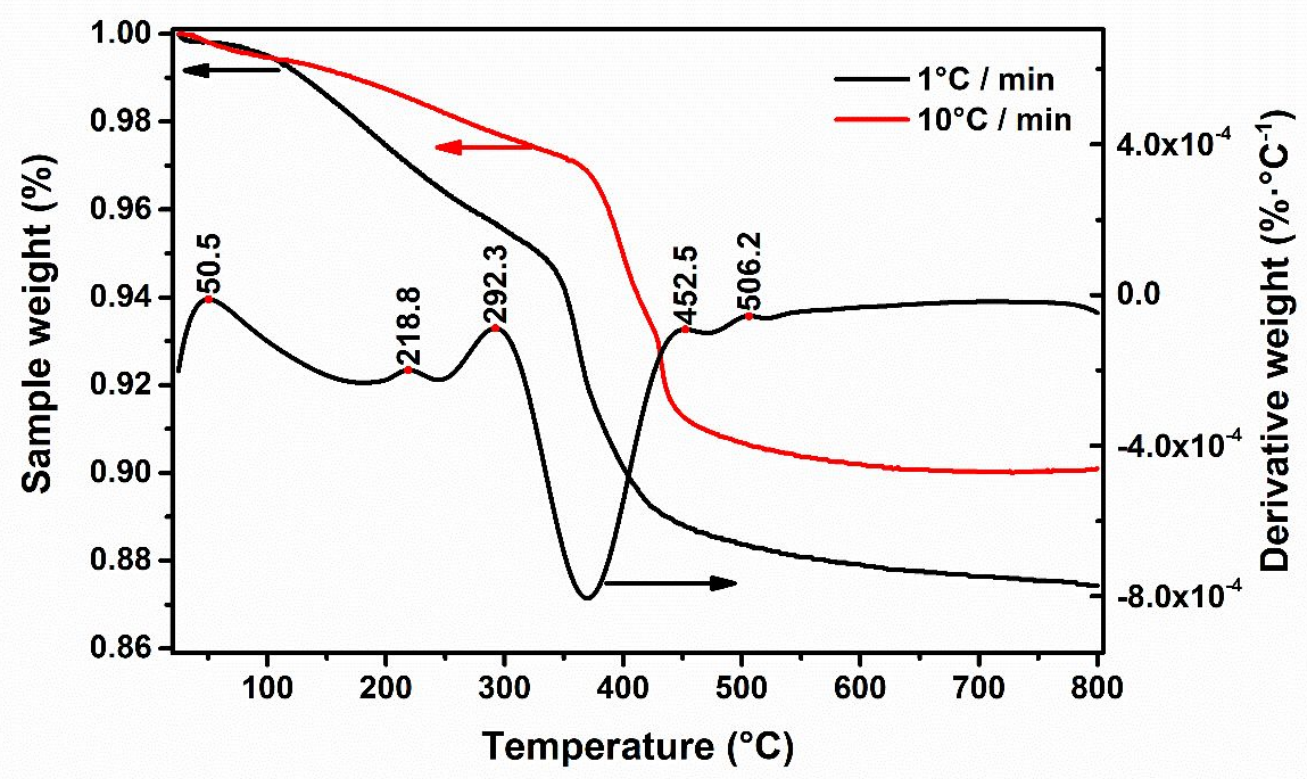

Figure S15. TG profile and the corresponding 1st order derivative of TG profile for 1$\mathrm{Yb}$ from $25^{\circ} \mathrm{C}$ to $800{ }^{\circ} \mathrm{C}$ with ramp rate of $1{ }^{\circ} \mathrm{C} / \mathrm{min}$ (black line); TG profile for $1-\mathrm{Yb}$ from $25^{\circ} \mathrm{C}$ to $800^{\circ} \mathrm{C}$ with ramp rate of $10^{\circ} \mathrm{C} / \mathrm{min}$ (red line) 


\section{Variable-temperature powder X-ray diffraction}

The in-situ PXRD patterns were collected with an Anton Paar XRK hot stage over the range $30{ }^{\circ} \mathrm{C} \leq \mathrm{T} \leq 600{ }^{\circ} \mathrm{C}$ between $2 \theta=10$ and $90^{\circ}$ on PANalytical Empyrean diffractometer. To avoid the contamination in the air, a stream of nitrogen was passed through the hot stage. Each pattern was collected for 10 minutes to obtain signals with a heating rate of $5{ }^{\circ} \mathrm{C} / \mathrm{min}$.

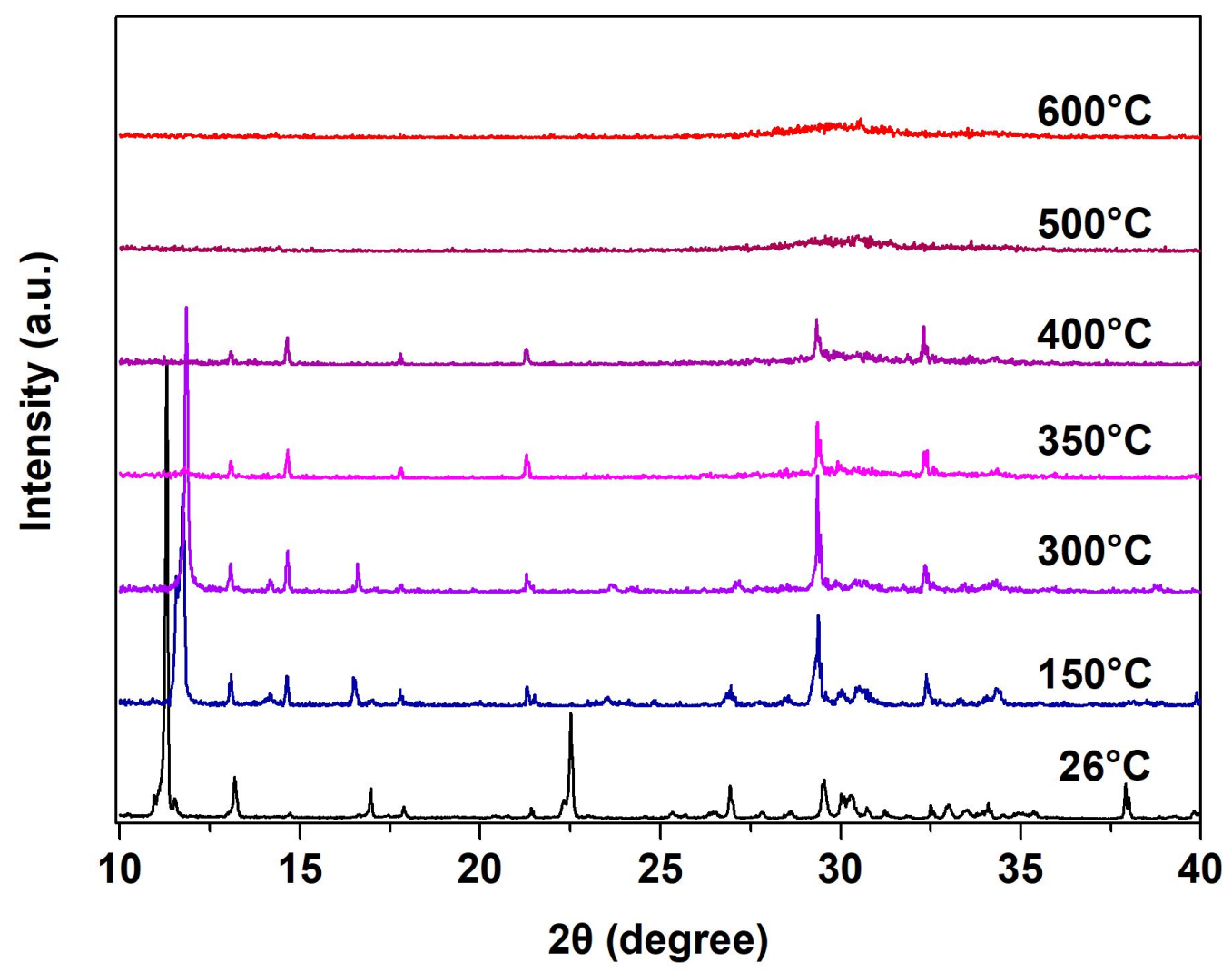

Figure S16. In-situ PXRD patterns of $1-\mathrm{Yb}$ from $26^{\circ} \mathrm{C}$ to $600^{\circ} \mathrm{C}$. 


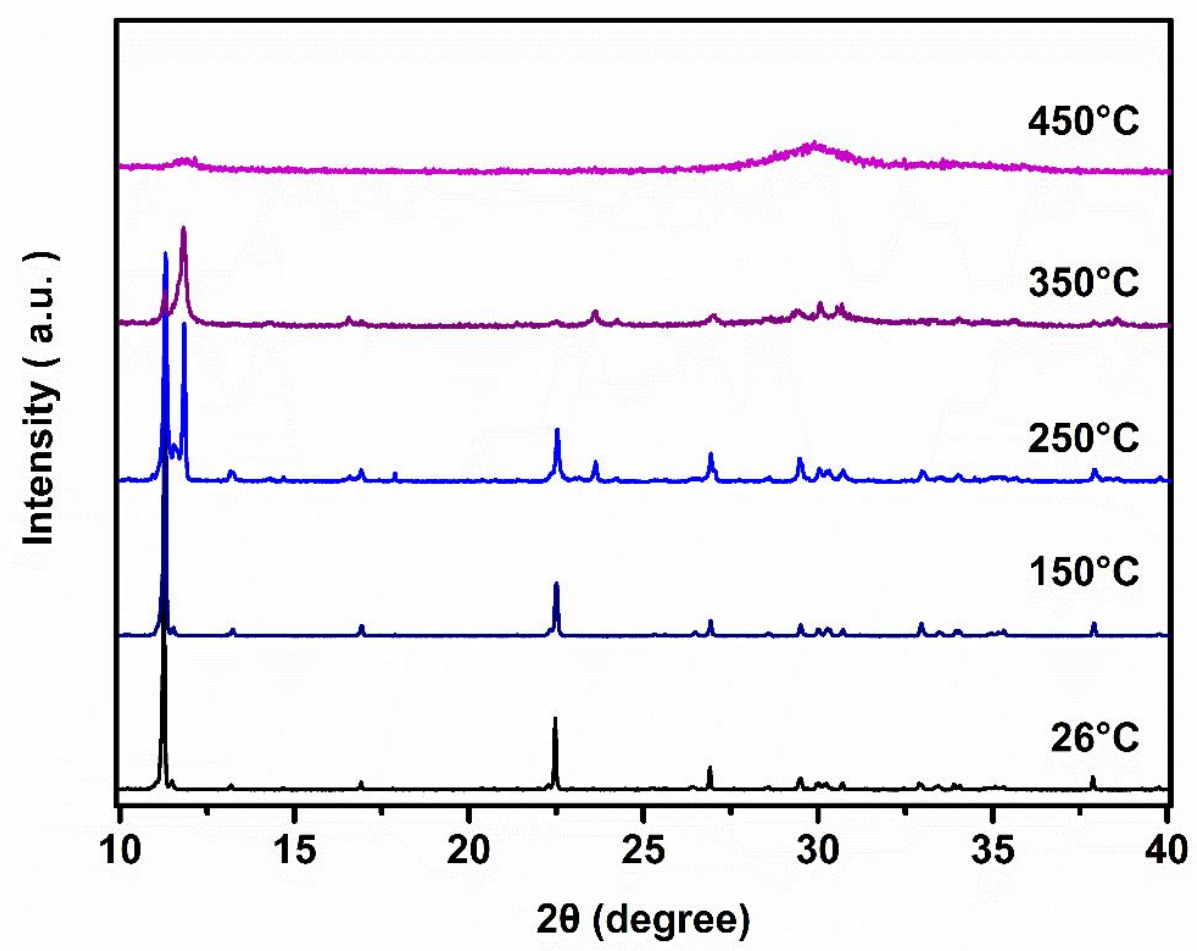

Figure S17. Room temperature PXRD patterns of $1-Y b$ samples calcinated at $26{ }^{\circ} \mathrm{C}$, $150{ }^{\circ} \mathrm{C}, 250^{\circ} \mathrm{C}, 350^{\circ} \mathrm{C}$ and $450{ }^{\circ} \mathrm{C}$ for 2 hours.

\section{Analysis of interlayer water content}

As shown in Fig S9-11, TGA and PXRD are employed to study the amount of water in this compound. The compound lost weight in four steps upon heating based on the 1st order derivative of the TGA as shown in Figure S9. The first weight loss ranges from $26{ }^{\circ} \mathrm{C}$ to $50^{\circ} \mathrm{C}$ corresponding to the loss of adsorbed water and gas molecules in the compound. The second weight loss ranges from $50^{\circ} \mathrm{C}$ to $300{ }^{\circ} \mathrm{C}$. No obvious change of positions for peaks except for the peak centered at $11.3^{\circ}$ was observed from the insitu PXRD patterns at $150{ }^{\circ} \mathrm{C}$ and $300^{\circ} \mathrm{C}$ compared to the room temperature PXRD patterns. The peak centered at $11.3^{\circ}$ shifted to $11.8^{\circ}$ at $150{ }^{\circ} \mathrm{C}$ and $300{ }^{\circ} \mathrm{C}$. This peak shift can be attributed to the decrease of layer distance. ${ }^{3}$ Similar results are also observed in room temperature PXRD patterns of $\mathrm{Yb}_{3}(\mathrm{OH})_{7} \mathrm{SO}_{4} \cdot \mathrm{H}_{2} \mathrm{O}$ samples calcinated at $150^{\circ} \mathrm{C}, 250^{\circ} \mathrm{C}$ as shown in Figure $\mathrm{S} 11$. We can draw the conclusion that the crystal structure of the $\mathrm{Yb}_{3}(\mathrm{OH})_{7} \mathrm{SO}_{4} \cdot \mathrm{H}_{2} \mathrm{O}$ maintained below $300{ }^{\circ} \mathrm{C}$ and the weight loss of compound can be attributed to the loss of interlayered water. The third weight loss ranges from $300{ }^{\circ} \mathrm{C}$ to $450^{\circ} \mathrm{C}$. The peak centered at $11.3^{\circ}$ disappears in the insitu PXRD patterns at $350{ }^{\circ} \mathrm{C}$ and $400{ }^{\circ} \mathrm{C}$ which indicates the dehydroxylation of the hydroxide layer. ${ }^{2}$ No sharp peak can be observed in the in-situ PXRD patterns when the compound was heated above $450{ }^{\circ} \mathrm{C}$ which suggests the low crystallinity of compound after further calcination.

Therefore, the weight loss ranges from $50{ }^{\circ} \mathrm{C}$ to $300{ }^{\circ} \mathrm{C}$ correspond to the interlayer water in this compound. However, no flat plateau can be observed in this range from 
TG profile with ramp rate as low as $1{ }^{\circ} \mathrm{C} / \mathrm{min}$ which make it difficult to determine the water content from the normal TG profile. In this way, isothermal TGA was employed to determine the amount of interlayer water in the compound. ${ }^{3}$ The sample was heated at $50^{\circ} \mathrm{C}$ for 3 hours to remove the adsorbed water and heated at $250{ }^{\circ} \mathrm{C}$ for 6 hours. $1.533 \%$ and $4.828 \%$ weight loss was observed after heating at $50{ }^{\circ} \mathrm{C}$ and $250{ }^{\circ} \mathrm{C}$ isothermally. The weight loss at $250^{\circ} \mathrm{C}$ corresponds to the loss of 1.412 moles of water per mole of $\mathrm{Yb}_{3}(\mathrm{OH})_{7} \mathrm{SO}_{4} \cdot \mathrm{H}_{2} \mathrm{O}$ which is close to the SCXRD result. However, due to the incomplete removal of adsorbed water at $50{ }^{\circ} \mathrm{C}$ and the slightly decomposition of hydroxy group at $250{ }^{\circ} \mathrm{C}$, the TGA result might not be accurate which explains the discrepancy of water contents in $\mathrm{Yb}_{3}(\mathrm{OH})_{7} \mathrm{SO}_{4} \cdot \mathrm{H}_{2} \mathrm{O}$ between the TGA and SCXRD results.

\section{References}

1. Hiltunen, L.; Niinisto, L., Ytterbium selenate octahydrate, $\mathrm{Yb}_{2}\left(\mathrm{SeO}_{4}\right)_{3}\left(\mathrm{H}_{2} \mathrm{O}\right)_{8}$. Cryst. Struct. Commun 1976, 5, 567-570.

2. Liang, J.; Ma, R.; Geng, F.; Ebina, Y.; Sasaki, T., $\mathrm{Ln}_{2}(\mathrm{OH})_{4} \mathrm{SO}_{4} \cdot \mathrm{nH}_{2} \mathrm{O}(\mathrm{Ln}=\operatorname{Pr}$ to $\mathrm{Tb} ; \mathrm{n} \sim 2$ ): A New Family of Layered Rare-Earth Hydroxides Rigidly Pillared by Sulfate lons. Chem. Mater. 2010, 22 (21), 6001-6007.

3. Constantino, V. R.; Pinnavaia, T. J., Basic properties of $\mathrm{Mg}^{2+}{ }_{1-x} \mathrm{Al}^{3+}{ }_{x}$ layered double hydroxides intercalated by carbonate, hydroxide, chloride, and sulfate anions. Inorg. Chem. 1995, 34 (4), 883-892. 